A Taste for

BROWN SUGAR 



\section{A Taste for}

\section{BROWN SUGAR}

Black Women in Pornography Mireille Miller-Young

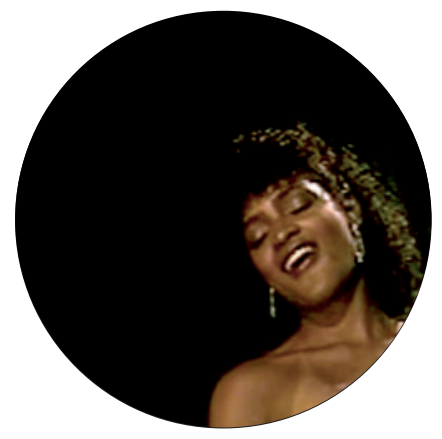

Duke University Press Durham and London 2014 
(C) 2014 Duke University Press

All rights reserved

Printed and bound at Grafos SA, Barcelona, Spain

Typeset in Minion Pro by Tseng Information Systems, Inc.

Library of Congress Cataloging-in-Publication Data

Miller-Young, Mireille, 1976-

A taste for brown sugar :

black women in pornography / Mireille Miller-Young.

pages $\mathrm{cm}$

Includes bibliographical references and index.

ISBN 978-o-8223-5814-5 (cloth : alk. paper)

ISBN 978-o-8223-5828-2 (pbk. : alk. paper)

1. Pornographic films - United States-History and criticism.

2. African American women in motion pictures.

3. African American motion picture actors and actresses. I. Title.

PN1995.9.S45M55 2014

$791.43^{\prime} 6538082-\mathrm{dc} 23$

2014013060

Cover art: Jeannie Pepper during her tour of Europe, Cannes,

France, 1986. Courtesy of JohnDragon.com. 